\title{
Growth and growth hormone secretion after bone marrow transplantation
}

\author{
R Brauner, M Fontoura, J M Zucker, A Devergie, J C Souberbielle, C Prevot-Saucet, J Michon, \\ E Gluckman, C Griscelli, A Fischer, R Rappaport
}

Abstract

This study analyses the growth and the growth hormone secretion of children given various conditioning protocols before bone marrow transplantation (BMT). Twenty nine children (14 boys, 15 girls) given BMT were classified according to their conditioning protocol: total body irradiation (TBI) given as a single exposure of 10 Grays (Gy, group I, 11 cases), or $8 \mathrm{~Gy}$ (group II, four cases), 12 Gy given as six fractionated doses (Group III, seven cases), or chemotherapy alone (group IV, seven cases). The arginine-insulin stimulated growth hormone peak, 2-7.5 years after BMT, was $>10 \mu \mathrm{g} / \mathrm{l}$ in all patients except four from group I (6.9-8.9 $\mu \mathrm{g} / \mathrm{l})$. A second growth hormone secretion evaluation was performed in 10 group I patients because of persistent low growth velocity despite a normal growth hormone peak. There were no significant changes in the mean (SEM) stimulated growth hormone peak $(18.4(2.2) v 20.1(3.6) \mu \mathrm{g} / \mathrm{l})$ at 3 $(0.3)$ to $5.2(0.6)$ years after BMT. The sleep growth hormone peaks and concentrations $(n=6)$ were normal. The mean cumulative height changes (SD) during the three years after BMT were: $-1.4(0.2)$ in group $I,-0.1$ $(0.4)$ in group II, $-0.4(0.2)$ in group III, and 1.5 $(0.5)$ in group IV; this was significant in groups I and IV. The final heights of two monozygotic twins (BMT donor and recipient) had differed by $17.5 \mathrm{~cm}$, despite them both having normal growth hormone peaks and puberty. Eight patients, treated for congenital immune deficiency syndrome, were growth retarded at the time of BMT. Of these, only those conditioned by chemotherapy alone had significant catch up growth (2 (0.6) SD) while those conditioned by a single 8 Gy exposure did not (0 (0.4) SD).

It is concluded that the total radiation dose is critical for growth evolution, as is the fractionation schedule. For the TBI doses and the interval since BMT studied, there was no correlation between growth hormone peak and the height loss. The rapidity of decreased growth velocity after TBI and the comparison between the monozygotic twins suggest that radiation induced skeletal lesions are partly responsible for the decreased growth.

(Arch Dis Child 1993; 68: 458-463)

Transplantation Unit, Hôpital St Louis, Paris

A Devergie

E Gluckman

Correspondence and reprint requests to:

Dr R Brauner, Paediatric

Endocrinology Unit, Hôpital des Enfants Malades, 149 rue de Sèvres 75743 Paris Cedex 15 , France.

Accepted 16 October 1992
Bone marrow transplantation (BMT) is increasingly used in the treatment of malignant and non-malignant diseases. ${ }^{1-3}$ As a result, a growing number of patients are long term survivors. The conditioning treatment for BMT is accompanied by late effects, some of which result in retarded growth. Growth hormone deficiency after hypothalamopituitary irradiation has been reported to be a potential cause of growth retardation in children treated with total body irradiation (TBI). ${ }^{+5}$ However, previous studies of the cause and frequency of growth retardation have been hampered by the cumulative effects of an initial prophylactic cranial irradiation - most of these children having acute lymphoblastic leukaemia - followed by TBI. More recently BMT has become the primary treatment for patients suffering from leukaemia and several other diseases.

This study evaluates the growth and growth hormone secretion of patients given various conditioning protocols before BMT. These children were divided into three groups according to their radiation doses and compared with a group of patients who had been conditioned for BMT by intensive chemotherapy alone.

\section{Patients and methods}

PATIENTS

Twenty nine children (14 boys, 15 girls) given BMT were evaluated at the Paediatric Endocrinology Unit, Hôpital des Enfants Malades, Paris. The evaluations were performed after informed consent had been obtained from the children or from their parents. None of the patients had received any previous radiation. Patients were prepared for BMT by chemotherapy alone or by chemotherapy plus TBI. The patients were assigned to one of four groups, according to their conditioning protocol for BMT (table 1): 11 patients were given 10 Grays (Gy) TBI as a single four hour exposure (group I), four patients were given $8 \mathrm{~Gy}$ TBI as a single four hour exposure (group II), seven patients were given $12 \mathrm{~Gy}$ TBI as six fractions of $200 \mathrm{cGy}$ over three consecutive days (group III). The remaining seven patients were prepared by chemotherapy alone (group IV). The mean (SEM) ages at BMT were $7 \cdot 3$ (1) years (group I), $3 \cdot 1(1 \cdot 1)$ years (group II), $5 \cdot 3(3 \cdot 1)$ years (group III), and $1 \cdot 3(0 \cdot 4)$ years (group IV). The irradiation was delivered with a 5.5 or $18 \mathrm{MV}$ linear accelerator. The dose rate was $4.2 \mathrm{cGy} / \mathrm{min}$ in group I and II and $50 \mathrm{cGy} / \mathrm{min}$ in group III. The conditioning chemotherapy varied depending on the initial disease. Twenty one patients were given cyclophosphamide (cases 1-9, 11-15, 2329). Twelve patients were given etoposide (cases 4, 16-22, 26-29). Seven patients were given melphalan (cases 10, 16-22). Eight patients were given cyclosporin to prevent graft-versus-host disease (cases 1, 3-5, 9, 10, 26, and 28). Prednisone was terminated within six months after transplantation in all cases. Grade 1 acute graft- 
Table 1 Characteristics, growth evolution, and biological data after BMT

\begin{tabular}{|c|c|c|c|c|c|c|c|c|}
\hline \multirow[b]{2}{*}{$\begin{array}{l}\text { Patient } \\
\text { No }\end{array}$} & \multirow[b]{2}{*}{ Sex } & \multirow[b]{2}{*}{ Diagnosis } & \multirow[b]{2}{*}{$\begin{array}{l}\text { Age at } \\
\text { BMT } \\
\text { (years) }\end{array}$} & \multirow[b]{2}{*}{$\begin{array}{l}\text { Interval since } \\
B M T \text { (years) }\end{array}$} & \multicolumn{3}{|c|}{ At time of first evaluation } & \multirow[b]{2}{*}{$\begin{array}{l}\text { SD height } \\
\text { changes after } \\
\text { three years }\end{array}$} \\
\hline & & & & & $\begin{array}{l}\text { Age } \\
\text { (years) }\end{array}$ & $\begin{array}{l}\text { Growth } \\
\text { hormone } \\
\text { peak }(\mu g / l)^{\star}\end{array}$ & $\begin{array}{l}I G F-I \\
(U / m l)\end{array}$ & \\
\hline $\begin{array}{l}\text { Group I (TBI I } \\
1 \\
2 \\
3 \dagger \\
4 \\
5 \\
6 \\
7 \\
8 \\
9 \\
10 \\
11 \\
\text { Mean (SE) }\end{array}$ & $\begin{array}{l}\text { Gy } \times 1) \\
\text { F } \\
F \\
F \\
F \\
F \\
F \\
M \\
F \\
M \\
M \\
M \\
(I)\end{array}$ & $\begin{array}{l}\text { ALL } \\
\text { ANL } \\
\text { ANL } \\
\text { ANL } \\
\text { Chronic leukaemia } \\
\text { ALL } \\
\text { ALL } \\
\text { ANL } \\
\text { ALL } \\
\text { ALL } \\
\text { ANL }\end{array}$ & $\begin{array}{l}1 \cdot 6 \\
2 \cdot 0 \\
4 \cdot 1 \\
5 \cdot 6 \\
7 \cdot 7 \\
8 \cdot 8 \\
9 \cdot 6 \\
10 \cdot 0 \\
10 \cdot 1 \\
10 \cdot 2 \\
10 \cdot 8 \\
7 \cdot 3(1)\end{array}$ & $\begin{array}{l}3 \cdot 5 \\
3 \cdot 0 \\
2 \cdot 0 \\
3 \cdot 5 \\
4 \cdot 3 \\
3 \cdot 2 \\
5 \cdot 0 \\
2 \cdot 0 \\
2 \cdot 5 \\
2 \cdot 0 \\
2 \cdot 0 \\
3 \cdot 6(0 \cdot 3)\end{array}$ & $\begin{array}{l}5 \cdot 1 \\
5 \cdot 0 \\
6 \cdot 1 \\
9 \cdot 1 \\
12 \cdot 0 \\
12 \cdot 0 \\
14 \cdot 6 \\
12 \cdot 0 \\
12 \cdot 6 \\
12 \cdot 2 \\
12 \cdot 8 \\
10 \cdot 9(1)\end{array}$ & $\begin{array}{r}7 \cdot 5 \\
20 \cdot 2 \\
12.9 \\
17 \cdot 5 \\
27 \cdot 0 \\
14 \cdot 0 \\
33 \cdot 3 \\
15 \cdot 6 \\
13 \cdot 9 \\
6 \cdot 9 \\
8 \cdot 9 \\
16 \cdot 1(2 \cdot 5)\end{array}$ & $\begin{array}{l}0 \cdot 13 \\
0 \cdot 8 \\
0 \cdot 38 \\
0 \cdot 88 \\
0.46 \\
1 \cdot 1 \\
1 \cdot 6 \\
0 \cdot 37 \\
0 \cdot 75 \\
0 \cdot 15 \\
1.06 \\
0 \cdot 7(0 \cdot 1)\end{array}$ & $\begin{array}{l}-2.3 \\
-1.8 \\
-1.5 \\
-2.1 \\
-2 \\
-1.1 \\
-0.7 \\
-1.9 \\
-0.8 \\
-0.3 \\
-1.1 \\
-1.4(0.2) 55\end{array}$ \\
\hline $\begin{array}{l}\text { Group II (TBI } \\
12 \\
13 \\
14 \\
15 \\
\text { Mean (SE) }\end{array}$ & $\begin{array}{l}\text { Gy } \times 1) \\
M \\
\text { F } \\
M \\
M \\
(I I)\end{array}$ & $\begin{array}{l}\text { CIDS } \\
\text { CIDS } \\
\text { CIDS } \\
\text { CIDS }\end{array}$ & $\begin{array}{l}1 \cdot 7 \\
2 \cdot 7 \\
3 \cdot 4 \\
4 \cdot 4 \\
3 \cdot 1(0 \cdot 6)\end{array}$ & $\begin{array}{l}2.5 \\
3.5 \\
6 \cdot 6 \\
6 \cdot 5 \\
4 \cdot 8(1 \cdot 0)\end{array}$ & $\begin{array}{l}4 \cdot 2 \\
5 \cdot 2 \\
10 \cdot 0 \\
10 \cdot 9 \\
7 \cdot 6(1 \cdot 7)\end{array}$ & $\begin{array}{l}16 \\
18 \cdot 3 \\
32 \cdot 6 \\
13 \cdot 8 \\
20 \cdot 2(4 \cdot 2)\end{array}$ & $\begin{array}{l}0.22 \\
0.53 \\
0.96 \\
1.65 \\
0.8(0.3)\end{array}$ & $\begin{array}{c}1.0 \\
-0.7 \\
0 \\
-0.6 \\
1-0.1(0.4)\end{array}$ \\
\hline $\begin{array}{l}\text { Group III (TB) } \\
16 \\
17 \\
18 \\
19 \\
20 \\
21 \\
22 \\
\text { Mean (SE) }\end{array}$ & $\begin{array}{l}2 \mathrm{~Gy} \times 6) \\
\mathbf{F} \\
\mathrm{F} \\
\mathrm{M} \\
\mathrm{M} \\
\mathrm{F} \\
\mathrm{F} \\
\mathrm{M} \\
(\mathrm{III})\end{array}$ & $\begin{array}{l}\text { Neuroblastoma } \\
\text { Neuroblastoma } \\
\text { Neuroblastoma } \\
\text { Neuroblastoma } \\
\text { Neuroblastoma } \\
\text { Lymphoma } \\
\text { Lymphoma }\end{array}$ & $\begin{array}{c}2 \cdot 2 \\
2 \cdot 5 \\
3 \cdot 4 \\
4 \cdot 3 \\
6 \cdot 7 \\
7 \cdot 6 \\
10 \cdot 5 \\
5 \cdot 3(0 \cdot 2)\end{array}$ & $\begin{array}{l}2.0 \\
2.9 \\
2.0 \\
3.0 \\
2.0 \\
2.5 \\
3.7 \\
2.6(0 \cdot 2)\end{array}$ & $\begin{array}{c}4 \cdot 2 \\
5 \cdot 4 \\
5 \cdot 4 \\
7 \cdot 3 \\
8 \cdot 7 \\
10 \cdot 1 \\
14 \cdot 2 \\
7 \cdot 9(1 \cdot 3)\end{array}$ & $\begin{array}{l}17 \cdot 6 \\
22 \cdot 6 \\
39 \cdot 0 \\
12 \cdot 5 \\
15 \cdot 3 \\
26 \cdot 1 \\
12 \cdot 7 \\
20 \cdot 8(3 \cdot 6)\end{array}$ & $\begin{array}{l}0.06 \\
0.8 \\
0.15 \\
2.0 \\
1.15 \\
1.5 \\
0.55 \\
0.9(0.3)\end{array}$ & $\begin{array}{l}-0.2 \\
-1.0 \\
0 \\
+0.3 \\
-1 \\
-0.5 \\
-0.2 \\
i-0.4(0.2)\end{array}$ \\
\hline $\begin{array}{l}\text { Group IV (che } \\
23 \\
24 \\
25 \\
26 \dagger \\
27 \dagger \\
28 \\
29 \\
\text { Mean (SE) }\end{array}$ & $\begin{array}{l}\text { notherapy) } \\
\text { F } \\
\text { M } \\
\text { F } \\
\text { F } \\
\text { M } \\
\text { M } \\
\text { M } \\
\text { (IV) }\end{array}$ & $\begin{array}{l}\text { CIDS } \\
\text { CIDS } \\
\text { CIDS } \\
\text { CIDS } \\
\text { Chronic leukaemia } \\
\text { Lymphohistiocytosis } \\
\text { CIDS }\end{array}$ & $\begin{array}{l}0.5 \\
0.5 \\
0.6 \\
0.9 \\
1.1 \\
2.3 \\
2.9 \\
1.3(0.4)\end{array}$ & $\begin{array}{l}2 \cdot 6 \\
3 \cdot 1 \\
2 \cdot 7 \\
2 \cdot 7 \\
3 \cdot 9 \\
2 \cdot 1 \\
3 \cdot 1 \\
2 \cdot 9(0 \cdot 2)\end{array}$ & $\begin{array}{l}3 \cdot 1 \\
3 \cdot 6 \\
3 \cdot 3 \\
3 \cdot 8 \\
5 \cdot 0 \\
4 \cdot 4 \\
6 \cdot 0 \\
4 \cdot 2(0 \cdot 3)\end{array}$ & $\begin{array}{l}23 \cdot 2 \\
28 \cdot 2 \\
38 \cdot 6 \\
28 \cdot 8 \\
17 \cdot 2 \\
16 \cdot 0 \\
40 \cdot 0 \\
27 \cdot 4(3 \cdot 6)\end{array}$ & $\begin{array}{l}0.97 \\
0.20 \\
1.0 \\
1.24 \\
0.05 \\
0.17 \\
0.49 \\
0.6(0.2)\end{array}$ & $\begin{array}{l}3 \\
3 \\
2.5 \\
1.5 \\
1.3 \\
-0.5 \\
0 \\
1 \quad 1.5(0.5) \$\end{array}$ \\
\hline
\end{tabular}

$\mathrm{ALL}=$ acute lymphoblastic leukaemia, $\mathrm{ANL}=$ acute non-lymphoblastic leukaemia, $\mathrm{CIDS}=$ congenital immune deficiency syndrome. CIDS due to leucocyte adhesion deficiency (cases 12 and 13), Wiskcott-Aldrich syndrome (case 14), Chédiak-Higashi syndrome (cases 15 and 29), or combined immune deficiency (cases 23-26).

$\star$ Growth hormone peak after arginine-insulin stimulation.

tAcute graft-versus-host disease.

†Acute graft-versus-host disease.
$\S p<0.05, \$ \$ p<0.001$ compared with height at time of BMT.

versus-host disease occurred in two group I patients (cases 3 and 9) and in two group IV patients (cases 26 and 27). It had been terminated at time of the study and all patients with haemopathy were in remission. No patient had raised blood pressure or clinical evidence of chronic graft-versus-host disease. The serum creatinine concentrations were within normal limits.

\section{PROTOCOL}

During the study period, a total of 65 patients were evaluated in the Paediatric Endocrinology Unit after BMT. They included (1) all those conditioned by TBI and chemotherapy in the Paediatric Oncology Unit, Institut Curie and the Bone Marrow Transplantation Unit, Hôpital St Louis during that period and (2) the first group of children conditioned by chemotherapy alone at the Immunology and Haematology Unit, Hôpital des Enfants Malades. Twenty nine of these patients were included in this study, and 36 were excluded because of factors other than conditioning for BMT interfering with growth or growth hormone secretion: previous cranial irradiation $(n=16)$, additional non-cranial irradiation $(n=4)$, disease relapse after a short time $(n=5)$, thalassaemia major $(n=1)$, interval since BMT less than two years $(n=6)$, BMT complications such as chronic graft-versus-hostdisease $(n=2)$, renal insufficiency $(n=1)$, or scoliosis $(n=1)$. Patients conditioned for BMT by thoracoabdominal irradiation were not included.

The 29 patients were followed up from the time of BMT. Height, weight, and genital maturation, basal plasma thyroid stimulating hormone and free thyroxine were recorded each year. The duration of this clinical follow up varied from three to 10 years. All patients but two (cases 7 and 11) were prepubertal throughout this follow up period. The first growth hormone evaluations, using arginine-insulin stimulation and plasma insulin-like growth factor-I (IGF-I) evaluation, were performed at least two years after transplantation (range 2-6.6 years, mean $3 \cdot 1(0.2)$ years). This interval was not significantly different from one group to another. A second growth hormone evaluation using arginine-insulin stimulation was performed in 10 patients. Five of these patients were also evaluated for their growth hormone secretion during sleep the night before the stimulation test. This second growth hormone evaluation was performed in all patients who continued to show a decreased growth velocity, in spite of a normal growth hormone peak response to the first stimulation and normal basal plasma thyroid stimulating hormone and thyroxine. In this 
group ( $n=10)$, the interval between the BMT and the first growth hormone evaluation was 3 $(0.3)$ years and $5 \cdot 2(0.6)$ years for the second evaluation. Three patients having a growth hormone peak $<10 \mu \mathrm{g} / \mathrm{l}$ and persistant low growth velocity were treated with human growth hormone through the French Pituitary Agency, at a dose of $0.5 \mathrm{U} / \mathrm{kg} /$ week given in six daily subcutaneous injections per week.

\section{METHODS}

Height was measured using a Harpenden stadiometer. The changes were expressed as the SD score for height based on the chronological age, and compared with the normal values for the French population. ${ }^{6}$ Growth hormone secretion was evaluated by arginine-insulin stimulation.? Sleeping growth hormone concentration was measured on blood samples taken every 20 minutes, from 2200 to 0400 hours. Plasma cortisol was measured at $\mathbf{0 8 0 0}$ hours and after insulin induced hypoglycaemia. Blood specimens were drawn and kept frozen at $-20^{\circ} \mathrm{C}$ until assayed for plasma IGF-I, free thyroxine, thyroid stimulating hormone, cortisol, and (in pubertal age boys) testosterone. Plasma growth hormone peak values over $10 \mu \mathrm{g} / \mathrm{l}$ were considered as normal as it is the limit set by the French Pituitary Agency below which human growth hormone treatment is given. Growth hormone concentrations during sleep of over $3 \mu \mathrm{g} / \mathrm{l}$ were considered normal. The normal limits for plasma free thyroxine were 12-28 $\mathrm{pmol} / \mathrm{l}$ and those for plasma thyroid stimulating hormone were $0 \cdot 6-5 \mathrm{mU} / \mathrm{l}$. Plasma IGF-I was determined in unextracted plasma collected over EDTA by the non-equilibrium technique of Furlanetto et al. ${ }^{8}$ The endocrine parameters were measured by radioimmunoassay.

The height changes within each group were analysed using the Wilcoxon matched paired test. All other comparisons were performed by the unpaired Wilcoxon two sample test. All results are expressed as mean (SEM).

\section{Results}

GROWTH HORMONE SECRETION AND PLASMA IGF-I At the first evaluation (table 1), the mean growth hormone peak values after arginine-insulin

Table 2 Evolution of growth hormone secretion and plasma IGF-I after BMT

\begin{tabular}{|c|c|c|c|c|c|c|c|}
\hline \multirow[b]{2}{*}{$\begin{array}{l}\text { Patient } \\
\text { No }\end{array}$} & \multicolumn{3}{|c|}{ First evaluation } & \multicolumn{4}{|c|}{ Second evaluation } \\
\hline & $\begin{array}{l}\text { Interval } \\
\text { since BMT } \\
\text { (years) }\end{array}$ & $\begin{array}{l}\text { Growth } \\
\text { hormone } \\
\text { peak } \\
(\mu g / l)^{\star}\end{array}$ & $\begin{array}{l}I G F-I \\
(U / m l)\end{array}$ & $\begin{array}{l}\text { Interval } \\
\text { since BMT } \\
\text { (years) }\end{array}$ & $\begin{array}{l}\text { Growth } \\
\text { hormone } \\
\text { peak } \\
(\mu g / l)^{\star}\end{array}$ & $\begin{array}{l}\text { Growth } \\
\text { hormone: } \\
\text { sleep } \\
(\mu g / l)^{\star}\end{array}$ & $\begin{array}{l}I G F-I \\
(U / m l)\end{array}$ \\
\hline $\begin{array}{r}2 \\
3 \\
4 \\
5 \\
7 \\
8 \\
9 \\
11 \\
13 \\
28\end{array}$ & $\begin{array}{l}3 \cdot 0 \\
2 \cdot 0 \\
3 \cdot 5 \\
4 \cdot 3 \\
5 \cdot 0 \\
2 \cdot 0 \\
2 \cdot 5 \\
2 \cdot 0 \\
3 \cdot 5 \\
2 \cdot 1\end{array}$ & $\begin{array}{r}20 \cdot 2 \\
12 \cdot 9 \\
17 \cdot 5 \\
27 \cdot 0 \\
33 \cdot 3 \\
15 \cdot 6 \\
13 \cdot 9 \\
8 \cdot 9 \\
18 \cdot 3 \\
16 \cdot 0\end{array}$ & $\begin{array}{l}0.8 \\
0 \cdot 38 \\
0 \cdot 88 \\
0 \cdot 46 \\
1.6 \\
0 \cdot 37 \\
0.75 \\
1.06 \\
0.53 \\
0.17\end{array}$ & $\begin{array}{l}4 \cdot 0 \\
5 \cdot 4 \\
5 \cdot 0 \\
8 \cdot 0 \\
7 \cdot 0 \\
4 \cdot 2 \\
2 \cdot 7 \\
2 \cdot 4 \\
7 \cdot 5 \\
6 \cdot 0\end{array}$ & $\begin{array}{c}25 \cdot 1 \\
7 \cdot 1 \\
11 \cdot 1 \\
16 \cdot 2 \\
33 \cdot 9 \\
22 \cdot 8 \\
10 \\
6 \cdot 5 \\
29 \cdot 4 \\
39 \cdot 1\end{array}$ & $\begin{array}{l}- \\
- \\
\overline{5} \cdot 2 \\
\overline{18} \cdot 6(5 \cdot 9) \\
31(8 \cdot 5) \\
\overline{40}(6 \cdot 7) \\
32 \cdot 2(7 \cdot 7)\end{array}$ & $\begin{array}{l}0 \cdot 80 \\
1 \cdot 30 \\
0 \cdot 88 \\
1 \cdot 30 \\
1 \cdot 30 \\
0 \cdot 90 \\
1 \cdot 20 \\
1 \cdot 0 \\
0 \cdot 85 \\
0 \cdot 20\end{array}$ \\
\hline Mean (SE) & $3(0 \cdot 3)$ & $18 \cdot 4(2 \cdot 2)$ & $0.7(0 \cdot 1)$ & $5 \cdot 2(0 \cdot 6)$ & $20 \cdot 1(3 \cdot 6)$ & & $1 \cdot 0(0 \cdot 1)$ \\
\hline
\end{tabular}

*After arginine-insulin stimulation.

†Peak (concentration). stimulation $(\mu \mathrm{g} / \mathrm{l})$ were $16 \cdot 1(2 \cdot 5)$ in group $\mathrm{I}$, $20 \cdot 2(4 \cdot 2)$ in group II, $20 \cdot 8(3 \cdot 6)$ in group III, and $27 \cdot 4(3.6)$ in group IV. Only the group I patients $(\mathrm{TBI}, 10 \mathrm{~Gy} \times 1$ ) had a significantly lower growth hormone peak value than that of group IV patients (chemotherapy alone, $\mathrm{p}<0.02$ ). Three patients from group I had growth hormone peak values $(\mu \mathrm{g} / \mathrm{l})$ below 10:7.5 (case 1$), 6.9$ (case 10 ), and 8.9 (case 11). The concomitant growth hormone peak and concentration during sleep of case 1 were normal $(11.6$ and $3.6 \mu \mathrm{g} / 1$ respectively). The plasma IGF-1 values were interpreted according to the sex and age of patients. ${ }^{9}$ Eleven of the 29 patients had plasma IGF-1 values below the lower limits of normal. These low values of plasma IGF-I were found in the two patients who were low growth hormone responders (cases 1 and 10) and in nine normal growth hormone responders (cases 3, 5, 12, 16, 18, 22, 24,27 , and 28). All had normal plasma thyroxine values. Plasma IGF-I values were not correlated with the body mass index (height/weight ${ }^{2}$ ). The mean values of this parameter in the whole population and in group I were normal (46 (5) centile).

At the second growth hormone evaluation (table 2), performed $2 \cdot 2$ years after the first evaluation, the mean growth hormone peak after arginine-insulin stimulation had not changed significantly $(18 \cdot 4(2 \cdot 2) v 20 \cdot 1(3 \cdot 6) \mu \mathrm{g} / \mathrm{l}, \mathrm{n}=10)$. This evaluation confirmed the low growth hormone peak in case 11 and showed a lower growth hormone peak in case 3. Five patients with normal stimulated growth hormone peaks had normal growth hormone peaks and concentrations during sleep. The mean plasma IGF-I value did not change significantly $(0.7(0 \cdot 1) v 0.9$ $(0 \cdot 1) \mathrm{U} / \mathrm{ml})$. Three of the four patients having low IGF-I values at the first evaluation had normal value at the second.

\section{OTHER ENDOCRINE DATA}

Plasma free thyroxine was low in three patients (cases 2, 6, and 19). The basal plasma thyroid stimulating hormone values were raised $(>5$ $\mathrm{mU} / \mathrm{l}$ ) in seven patients (cases $1,2,4-6,10,17$ ). Six of them belonged to group I and one to group III. These patients were therefore given L-thyroxine replacement treatment $(50-100 \mu \mathrm{g} /$ $\mathrm{m}^{2} /$ day) from that time. This treatment did not improve their growth rate. Basal and insulin stimulated plasma cortisol concentrations were normal in all cases (data not shown). Only two boys were pubertal (cases 7 and 11) with plasma testosterone values of 2.9 and $9.7 \mathrm{nmol} / 1 \mathrm{respect-}$ ively.

\section{GROWTH}

The growth evolution of each group was different. All the patients were followed up for at least three years after BMT. The mean cumulative height changes (SD) during this period were: $-1 \cdot 4(0 \cdot 2)(\mathrm{p}<0.001)$ in group I (compared with height at BMT), $-0 \cdot 1(0.4)$ (not significant) in group II, $-0.4(0.2)$ (not significant) in group III, and $1.5(0.5)(\mathrm{p}<0.05)$ in group IV (table 1). As shown in fig 1 , the mean SD score for height decreased until the fourth year after irradiation in group I. In contrast, there were no changes in 


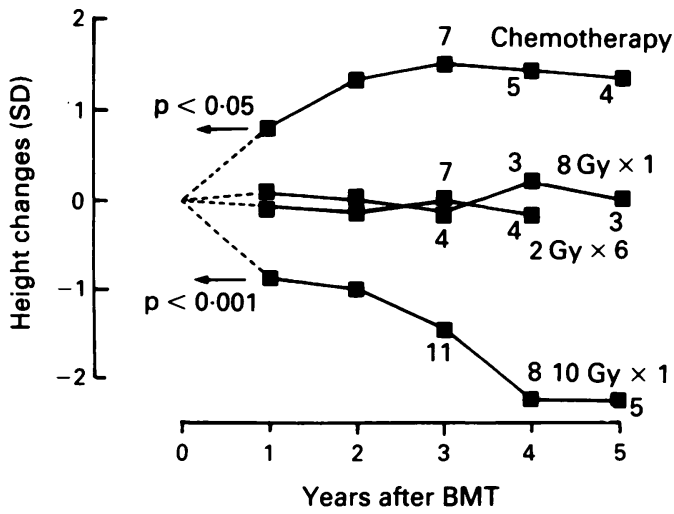

Figure 1 Mean cumulative height changes from BMT according to the conditioning protocol with number of patients: $T B I$ (group I 10 Gy $\times 1$, group II 8 Gy $\times 1$, group III $2 G y \times 6)$, or chemotherapy (group IV).

groups II and III, and catch up growth was observed until the third year in group IV. The evolution of the individual data is shown in fig 2. The growth of the patients with growth hormone peak $<10 \mu \mathrm{g} / 1$ (cases $1,3,10$, and 11 ) was similar to that of the other patients in group I having normal growth hormone secretion. Three of
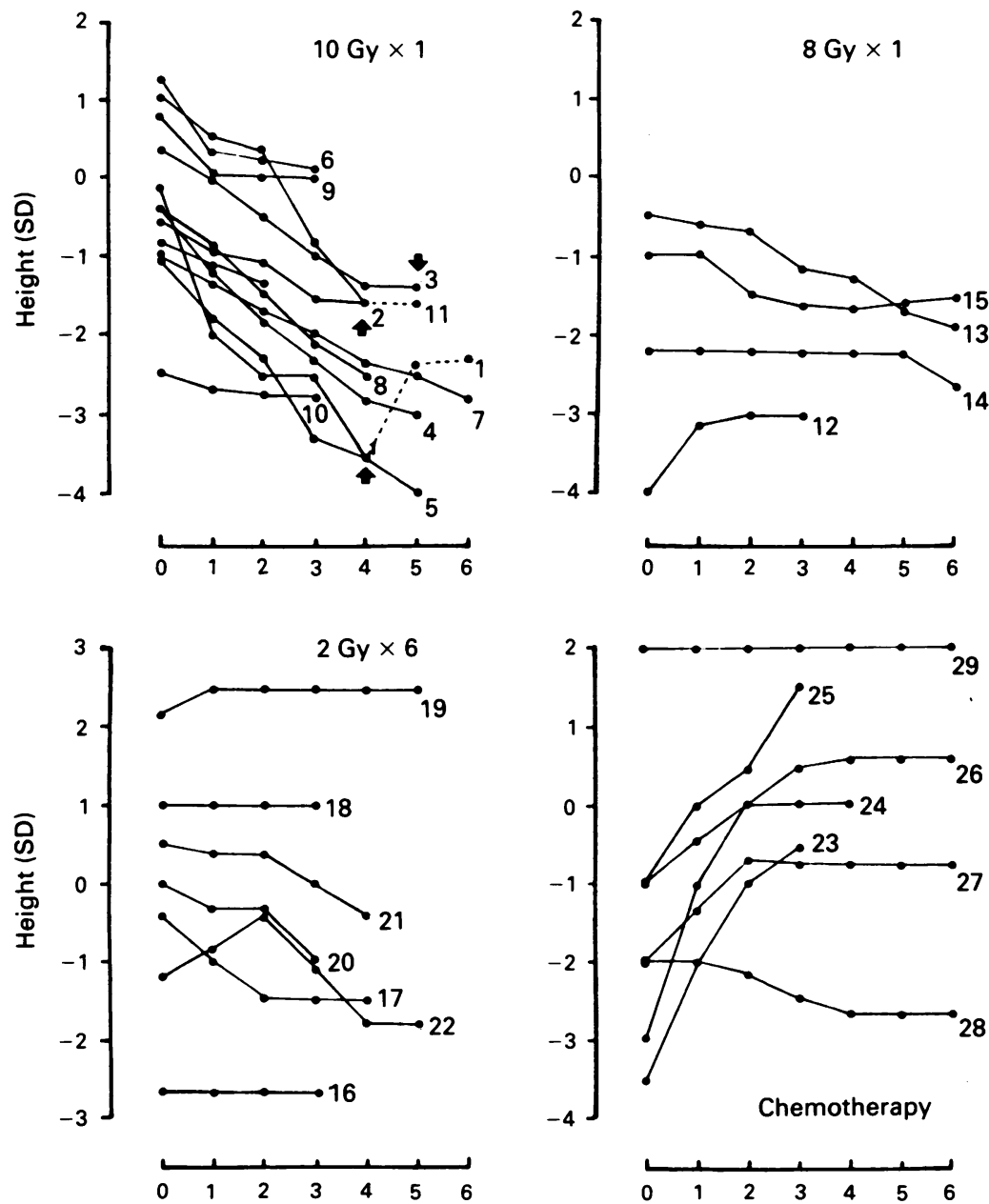

Years after BMT

Figure 2 Individual changes after BMT, according to the conditioning protocol. Patients given $10 \mathrm{~Gy} T B I$ in a single exposure (group I) showed rapid and significant growth

retardation, while growth was normal after $1 \times 8$ Gy (group II) and after $6 \times 2$ Gy (group III). Catch up growth occurred in patients with congenital immune deficiency syndromes conditioned by chemotherapy (group IV, cases 23-26). Growth hormone deficiency occurred in cases 1,3 , 10, 11. Arrows indicate the start of human growth hormone treatment.
Growth hormone $(\mu \mathrm{g} / \mathrm{l}) * 11.5 \quad 33.3 \quad 39.0$ IGF-1 (U/ml) $\quad 0.78 \quad 1.2$

Testosterone $(\mathrm{nmol} / \mathrm{l}) \quad 2.9 \quad 14.2$

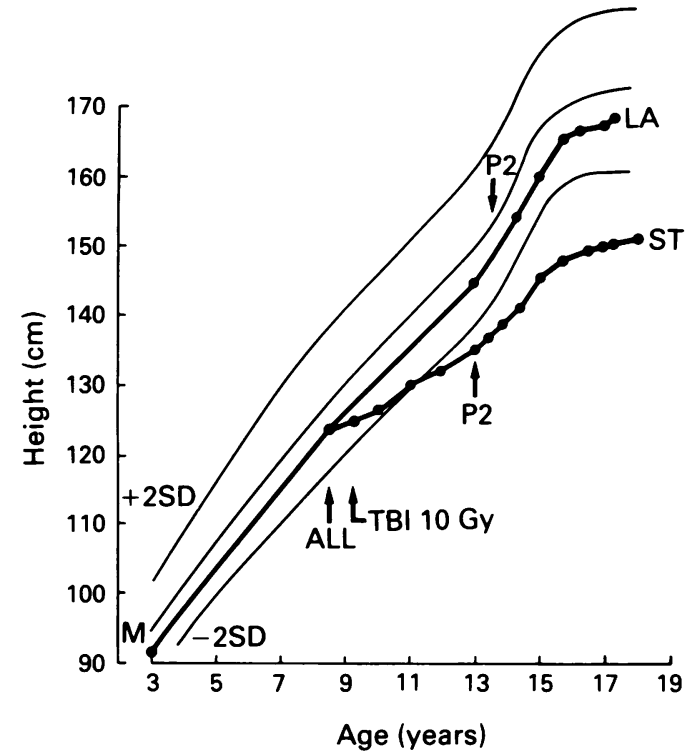

Figure 3 Growth of monozygotic twins: case $7(S T)$ was given a BMT for acute lymphoblastic leukaemia $(A L L)$ from his brother LA. He was conditioned by TBI. The plasma growth hormone peak after the arginine-insulin stimulation test ${ }^{\star}$ and the plasma IGF-I of $S T$ were normal. P2 indicates the onset of puberty.

them were treated with human growth hormone. The growth velocity was normalised in one and increased for age in a second (fig 2). The extent of growth retardation after a single $10 \mathrm{~Gy}$ exposure despite normal growth hormone secretion was documented by comparing the growth evolution of monozygotic twins: the case 7 boy had a final height $17.5 \mathrm{~cm}$ below that of his brother who donated the bone marrow for transplantation. This occurred in spite of case 7 having a normal growth hormone peak, plasma IGF-I concentration, and a similar age at pubertal development (fig 3). Growth was further analysed in the eight patients treated for congenital immune deficiency syndrome who were growth retarded at the time of BMT. The height changes after three years of those given TBI ( $8 \mathrm{~Gy}$ single exposure, cases 12-15) were compared with those of the patients given chemotherapy alone (cases 23-26) (fig 2). The TBI group had no change in mean height $(0(0.4) \mathrm{SD})$ but the chemotherapy group had a mean height gain of $2(0.6)$ SD indicating strong catch up growth. The difference between these two groups was significant $(p<0.01)$. Data of upper segment length, measured as the sitting height, were collected at the first evaluation $(3 \cdot 8$ $(0.7)$ years after BMT) in 14 patients. When expressed as the SD score, it was found to be a mean (SD) $-1.8(0.4)$ while the concomitant height was $-1 \cdot 7(0 \cdot 4)$.

\section{Discussion}

Short stature could be a severe side effect in children treated by BMT. We therefore asked two questions. First, what is the risk of growth hormone deficiency due to irradiation of the hypothalamus and pituitary as part of TBI? Patients who had previously been 
given cranial irradiation were not included in this study. Second, is the growth related to the conditioning protocol? Only the group of children who had been exposed to a single exposure of $10 \mathrm{~Gy}$ failed to grow, while patients given single dose of $8 \mathrm{~Gy}$ or a fractionated dose of $12 \mathrm{~Gy}$ grew normally and those conditioned by chemotherapy had catch up growth.

Growth hormone deficiency induced by TBI is one of the potential causes of growth retardation. Its frequency is difficult to evaluate as the published studies were performed after various protocols of TBI, times after TBI, and methods of growth hormone stimulation. The growth hormone peak $(\mu \mathrm{g} / \mathrm{l})$ after one stimulation in patients without previous cranial irradiation was found to be $7-10 \mu \mathrm{g} / \mathrm{l}$ in $6 / 18$ patients evaluated by Sanders et $a l,{ }^{+}$below $8 \mu \mathrm{g} / 1$ in $10 / 18$ patients evaluated after $10 \mathrm{~Gy}$ by Borgström et al,${ }^{10}$ below $10 \mu \mathrm{g} / \mathrm{l}$ in $1 / 5$ patients evaluated after $9-10 \mathrm{~Gy}$ by Papadimitriou et $a l,{ }^{\prime \prime}$ and also below $10 \mu \mathrm{g} / \mathrm{l}$ in $12 / 25$ patients evaluated after 11-15.2 Gy by Ogilvy-Stuart et al. ${ }^{12}$ The spontanenous growth hormone secretion was found to have a below normal number of peaks and amplitude in $7 / 9$ patients evaluated by Borgström et $a l^{10}$ and only below normal amplitude in 9/10 evaluated after 10 or 12 Gy by Hovi et al. ${ }^{13}$ This last study included three patients who had previously received cranial irradiation. It showed that the mean nocturnal growth hormone concentrations decreased with the length of the follow up period. In these studies, the TBI was delivered as a single dose or in six fractions and the duration of follow up extended from one to 14 years. In the present study, the growth hormone secretion was evaluated after a post-transplant interval longer than two years. Among the 22 patients conditioned by TBI, only four had growth hormone peak below $10 \mu \mathrm{g} / \mathrm{l}$. All belonged to group I (10 Gy in a single exposure), which included 11 patients. The patients who had a second growth hormone evaluation performed $2 \cdot 2$ years after the first evaluation because of a persistant decrease in their growth velocity, showed no change in the mean growth hormone peak. Only one patient with a normal growth hormone peak at the first growth hormone evaluation became growth hormone deficient at the second evaluation. The plasma IGF-I concentration was low in several patients at the first evaluation without any relationship with the body mass index. Some of the low values became normal at the second evaluation. This normalisation suggests that the low initial values may have been due to factors other than decreased growth hormone secretion, such as initial chemotherapy or disease. There was not a good agreement between the growth hormone peak and plasma IGF-I values. These data, taken together, suggest that TBI at a single dose of $10 \mathrm{~Gy}$ or more may partially reduce growth hormone secretion. The growth hormone secretion of patients given $8 \mathrm{~Gy}$ was normal in the present study. Longer follow up of more homogeneous cohorts are required to evaluate the frequency and the delay of growth hormone deficiency after various doses of TBI.

What is the relationship between growth hormone secretion and growth after TBI?
Factors other than growth hormone deficiency, such as chronic graft-versus-host disease, corticosteroid treatment, or renal insufficiency may be responsible for the growth retardation after BMT. Any patient who presented with these complications was excluded from this study. The mean body mass index was normal and thyroid insufficiency was compensated. A rapid decrease in growth velocity occurred only in the patients given 10 Gy TBI in a single exposure. Conversely, the patients given $12 \mathrm{~Gy}$ in six fractions had normal growth velocity. Among the patients growth retarded at BMT, only those conditioned by chemotherapy had catch up growth. Those conditioned by $8 \mathrm{~Gy}$ single exposure did not, in spite of a normal growth hormone peak after stimulation. This lack of catch up growth suggests that skeletal lesions may have occurred in irradiated patients. This finding must be confirmed on a larger group, however, as the difference may be due in part to the patients conditioned by chemotherapy alone being younger. There was no correlation between the growth hormone peak and the height loss in the $10 \mathrm{~Gy}$ TBI group; this was also found by Hovi et al..$^{13}$ Borgström et al found a decreased growth rate in patients given a single $10 \mathrm{~Gy}$ dose. ${ }^{10}$ The slowdown began during the first year after transplant and they suffered a total height loss of about 2 SD after 5 years. Bushhouse et al found a mean height loss of 0.67 SD during the two years after a single $7 \cdot 5 \mathrm{~Gy}$ TBI dose. ${ }^{14}$ Sanders et al found that the type of TBI $(10 \mathrm{~Gy} \times 1$ or 2 or $2.25 \mathrm{~Gy} \times 6$ or 7 ) did not appear to affect height until three years or more after transplant, ${ }^{+}$at which time those who had received fractionated TBI grew significantly taller than those who had received a single exposure. These data and the comparison between the two twins suggest that the decrease in growth velocity secondary to TBI may be partly due to cartilage and bone lesions. This is comparable with the data observed in children who received spinal irradiation for medulloblastoma. A significant failure to grow occurred within the first two years after irradiation before the decrease in growth hormone secretion. ${ }^{1516}$ Neuhauser et al described roentgenograph vertebral body changes after spinal irradiation. ${ }^{17}$ They showed the importance of the total radiation dose, duration of treatment, and age at irradiation. Doses of $10 \mathrm{~Gy}$ delivered in one week produced changes in children younger than 2 years. ${ }^{17}$ Tefft showed that these changes occurred after lower doses when delivered to children less than 1 year old. ${ }^{18}$ Willi et al found a persistant decreased growth velocity in patients who had transplants for neuroblastoma. ${ }^{19}$ The role of chemotherapy, especially melphalan, was discussed. However, their patients also received local radiotherapy, which may decrease growth velocity. Papadimitriou et al have found that sitting height SD scores had been affected more than subischial leg length in 13 children evaluated after a mean interval time of $3 \cdot 2$ years. "In the present study, sitting height and total height, evaluated $3 \cdot 8$ years after BMT, were similar.

In conclusion, the decrease in growth velocity occurred only in patients conditioned for transplantation by $10 \mathrm{~Gy}$ delivered in a single 
exposure. The mechanism of this decrease is unknown. Four patients had growth hormone peaks in the lower range. The normalisation of their growth velocity on standard doses of human growth hormone treatment favours the role of this growth hormone decrease in the decreased growth. However, the absence of agreement between growth hormone peak, plasma IGF-I concentrations, and growth in this group indicates that the contribution of growth hormone deficiency to the decreased growth is not clear. Other mechanisms for growth retardation were ruled out. As other studies showed that single dose induced complications more frequently than fractionated doses, our data are a further argument favouring conditioning by fractionated schedule or chemotherapy.

We thank Dr J Dutreix and Dr J M Cosset for helpful discussion and $M$ Lacroix and $C$ Chamot for secretarial assistance.

Supported by a grant from Assistance Publique-Hôpitaux de Supported
Paris, 1988.

1 Thomas ED, Storb R, Clift RA, et al. Bone-marrow transplantation. $N$ Englf Med 1975; 292: 832-43.

2 Thomas ED, Storb R, Clift RA, et al. Bone-marrow transplantation. N Engl F Med 1975; 292: 895-902.

3 Borton MM, Rimm AA. Increasing utilization of bone marrow transplantation. Transplantation 1986; 42: 229-34.

4 Sanders JE, Pritchard S, Mahoney P, et al. Growth and development following marrow transplantation for development following marrow

5 Leiper AD, Stanhope R, Lau T, et al. The effect of total body irradiation and bone marrow transplantation during childhood and adolescence on growth and endocrine function. $B$ f Haematol 1987; 67: 419-26.

6 Sempé P, Pédron G, Roy-Pernot MP. Auxologie, méthodes et séquences. Paris: Theraplix, 1979.
7 Penny R, Blizzard RM, Davis MT. Sequential arginine and insulin tolerance tests on the same day. $\mathcal{F}$ Clin Endocrinol Metabl 1969; 29: 1499-501.

8 Furlanetto RW, Underwood LE, Van Wyk JJ, d'Ercole AJ. Estimation of somatomedin-C levels in normals and patients with pituitary disease by radioimmunoassay. $\mathcal{f}$ Clin Invest 1977; 60: 648-57.

9 Rosenfeld RG, Wilson DM, Lee PDK, Hintz RL. Clinical relevance of the somatomedins. In: Hintz RL, Underwood LE, eds. Somatomedins and other peptide growth factors: relevance to pediatrics. Report of the Eighty-Ninth Ross Conference on Pediatric Research Colombus, Ohio: Ross

10 Borgström B, Bolme P. Growth and growth hormone in children after bone marrow transplantation. Horm Res 1988; 30: $98-100$.

11 Papadimitriou A, Uruena M, Hamill G, Stanhope R, Leiper AD. Growth hormone treatment of growth failure secondary to total body irradiation and bone marrow transplantation. Arch Dis Child 1991; 66: 689-92.

12 Ogilvy-Stuart AL, Clark DJ, Wallace WHB, et al. Endocrine deficit after fractionated total body irradiation. Arch Dis Child 1992; 67: 1107-10.

13 Hovi L, Rajantie J, Perkkiö M, Sainio K, Sipilä I, Siimes MA. Growth failure and growth hormone deficiency in children after bone marrow transplantation for leukemia. Bone Marrow Transplant 1990; 5: 183-6.

14 Bushhouse S, Ramsay NKC, Pescovitz OH, Kim T, Robison LL. Growth in children following irradiation for bone marrow transplantation. Am $\mathcal{F}$ Pediatr Hematol Oncol 1989; 11: $134-40$.

15 Brauner R, Rappaport R, Prevot C, et al. A prospective study of the development of GH deficiency in children given cranial irradiation, and its relation to statural growth. $\mathscr{f} \mathrm{Clin}$ Endocrinol Metab 1989; 68: 346-51.

16 Rappaport R, Brauner R. Growth and endocrine disorders secondary to cranial irradiation. Pediatr Res 1989; 25: 561-7.

17 Neuhauser EBD, Wittenborg MH, Berman CZ, Cohen J. Irradiation effects of roentgen therapy on the growing spine. Irradiation effects of roentgen

18 Tefft M. Radiation effect on growing bone and cartilage. In: Vaeth JM, ed. Radiation effects and tolerance. Normal tissue. Front Radiat Ther Oncol 1972; 6: 289-311.

18 Willi SM, Cooke K, Goldwein J, August CS, Olshan JS, Moshang Jr T. Growth in children after bone marrow transplantation for advanced neuroblastoma compared with growth after transplantation for leukemia or aplastic anemia. f Pediatr 1992; 120: 726-32. 